\title{
BREEDING STATUS OF THE FORSTER'S TERN IN MANITOBA
}

\author{
by David R. M. Hatch, Manitoba Museum of Man and Nature, \\ 190 Rupert Avenue, Winnipeg
}

The breeding distribution of the Forster's Tern (Sterna forsteri) in the Prairie Provinces was reviewed by Gerrard and Whitfield (1971). They cited somewhat vague records of early observations by Macoun, Taverner, and Gunn for lakes Winnipeg, Winnipegosis, and Manitoba. These are large lakes with hundreds of miles of shoreline, and consequently, unspecified nesting localities have limited value. More specific nesting localities have been documented (Table I, Figure 1).

According to studies by McNicholl (1971:66-69) and others summarized by him, Forster's Terns usually nest in fairly dense stands or "islands" of bulrush (Scirpus), cattail (Typha), and similar plants in relatively open marshes or marshy bays. My observations have revealed three distinct types of nest sites: on muskrat houses, on mats of floating year-old vegetation, and on platforms of fresh vegetation constructed by the pair. The last situation is the least common; however, one colony seen by the author was composed exclusively of nests of this type. These nests were platforms in moderately dense vegetation, each surrounded by a fringe of open water from which the nest material apparently had been taken. There was only one nest on each platform. Table I shows the type of structure used in each colony.

Between 1969 and 1971, inclusive, I visited nearly all the major marshes and lakes in Manitoba's Interlake region. Forster's Terns were found nesting on the western side of Lake Winnipeg in the Netley marshes and in marshes at Gimli, Riverton, Hecla Island, and Matheson Island. No evidence of nesting was seen on any of the interior marshes or lakes between lakes Winnipeg and Manitoba, including East, West, and North Shoal lakes. In two marshes on the east side of Lake Manitoba, namely Marshy Point southwest of Lundar and the St. Ambroise marsh, Forster's Terns were present, but there was no evidence of nesting. However, Forster's Terns were photographed nesting at Marshy Point in 1970 by Mr. George Cotter who found eight nests in one colony and about 20 in another. A colony of six nests, containing two to three eggs each, was visited in the Pineimuta marsh border-

TABLE No. 1

Nesting Details of Forster's Tern in Manitoba

\begin{tabular}{|c|c|c|c|}
\hline Colony Location & $\begin{array}{c}\text { Year } \\
\text { Last Visited }\end{array}$ & $\begin{array}{c}\text { Dominant } \\
\text { Vegetation }\end{array}$ & $\begin{array}{l}\text { Nest } \\
\text { Type* }\end{array}$ \\
\hline Netley marsh & 1971 & Scirpus \& Typha & $A \& B$ \\
\hline Gimli & 1971 & Sparganium & $\mathrm{B} \& \mathrm{C}$ \\
\hline Riverton & 1970 & Sparganium & $\mathrm{C}$ \\
\hline Hecla Island & 1971 & Typha & $A \& B$ \\
\hline Matheson Island & 1971 & Sparganium & $A \& B$ \\
\hline Marshy Point, Lundar & 1970 (Cotter) & Typha & $A \& B$ \\
\hline $\begin{array}{l}\text { Pineimuta marsh, } \\
\text { Lake St. Martin } \\
\text { South Lake, Riding }\end{array}$ & 1970 & Typha & A \\
\hline $\begin{array}{l}\text { Mountain Nat. Park } \\
\text { "Turtle Marshes", }\end{array}$ & 1971 & Scirpus & A \\
\hline Dauphin Lake & 1971 & Scirpus \& Typha & $A \& B$ \\
\hline
\end{tabular}


ing Lake St. Martin on June 25, 1969 ; this was the only evidence of nesting in the Fairford River-Lake St. Martin complex.

A colony on the east side of Netley marsh, visited June 28, 1971, contained 38 nests scatttered over a 400-yard distance and fringing a Franklin's Gull colony. All nests contained from one to three eggs. When visited July 12 , 1971, the Gimli colony had largely flightless young with only five nests harbouring eggs. This colony consisted of approximately 100 pairs and was located two miles south of Gimli in a marsh bordering Lake Winnipeg.

A colony in the Riverton marsh (sec. 24-24-4E) visited on July 28, 1970 , had 27 nesting platforms with some young already on the wing and others only three to four days old. One colony in the Hecla marsh (sec. 9-24-5E) was visited in 1970 and 1971. Despite disruptions due to a causeway being built through this colony in 1971, young were still produced. The colony had approximately 40 nests all containing eggs on June 19, 1971. Also, at Hecla marsh, colonies were seen in sections 8-24-5E and 17-24-5E on June 19,1971 where they have traditionally nested, although in 1970, high water coupled with wind-tides prevented them from nesting at these sites.

The Matheson Island colony was in a marsh on the southwest side of the island and was visited in both 1970 and 1971. On June 25, 1971, the colony contained 17 nests, mostly with young. This colony was unique by being in a marsh bordered by conifers and aspen on the limestone outcrop of Matheson Island. It is on the northeastern extremity of the species' breeding range in the Prairie Provinces.

The species was not recorded in Riding Mountain National Park in surveys made between 1938 and 1946 (Soper, 1953). It has now, however, gained a foothold and has been recorded nesting annually since 1968 when the author found four nests. Each year the nests have been in a narrow band of bulrush on South Lake. Only two nests, each with two eggs, were found on June 17, 1971, and as this bulrush stand is becoming thin, the species may soon be lost from the

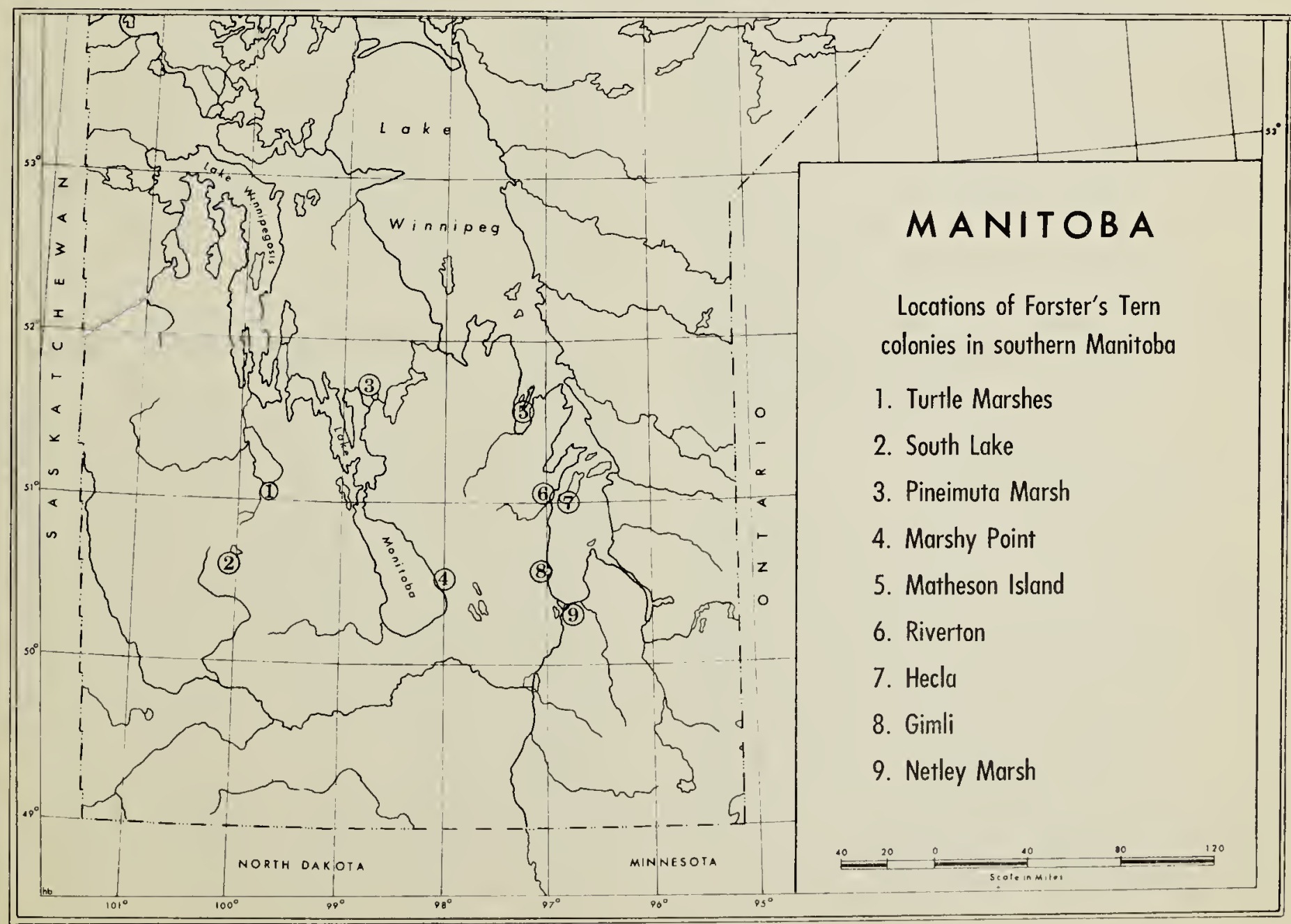


park as a breeding bird. This was the smallest of the colonies discovered.

Forster's Terns were recorded nesting in the "Turtle Marshes" on the south side of Dauphin Lake, two miles upstream from the mouth of the Turtle River. This colony was visited on July 13,1971 and at this time contained several young of which at least 15 were too small to fly. The number of adults was estimated to be 60 .

There are several factors limiting the breeding distribution of Forster's Tern in the Interlake, of which food supply may well be the most important. Many of the water bodies in the Interlake are infertile, and, as a result, animal life in the form of minnows, aquatic insects, dragonflies, etc. is limited. As these are staple foods of Forster's Tern, the number of breeding terns is small. There is a lack of marshes with moderately dense stands of bulrush, cattail, or bur-reed (Sparganium) for nesting cover. Marshes with both good nesting habitat and an abundant food source are scarce in the Interlake, although some of the marshes bordering lakes Winnipeg and Manitoba are exceptions. Lake Winnipeg is the eastern border of the breeding range of this species. East of this lake the habitat is boreal, and marshes are replaced by bogs surrounded by forest.

\section{Acknowledgments}

I wish to thank George Cotter and Martin McNicholl for the use of their data.

\section{LITERATURE CITED}

Gerrard, J. M., and D. W. A. Whitfield. 1971. Breeding distribution of Forster's Tern in the Prairie Provinces. Blue Jay, 29:19-22.

McNicholl, M. K. 1971. The breeding biology and ecology of Forster's Tern (Sterna forsteri) at Delta, Manitoba. Un published M.Sc. thesis, University of Manitoba. $652 \mathrm{pp}$.

Soper, J. D. 1953. Birds of Riding Mountain National Park, Manitoba, Canada. Can. Wildl. Serv., Wildl. Mgt. Bulletin, Series 2, Number $6,54 \mathrm{pp}$.

\section{CATBIRD AT CHURCHILL, MANITOBA}

\section{by R. Barry Ranford, 1345 Kendall Road, Mississauga, Ontario and}

\section{Mrs. Linda McKeane, 5 Sherwood Avenue, Toronto 12, Ontario}

While on a bird-watching and photographic trip to Churchill this spring, we had the good fortune to find a pair of nesting Pigeon Hawks (Falco columbarius) in a small spruce grove across from the Northern Lights Observatory east of Fort Churchill. We spent several days photographing these hawks and it was during this time on June 18, 1971 that a Catbird (Dumetelia carolinensis) was first heard and later seen.

It was about 10:00 a.m. and slightly overcast when we heard a distinctive cat-like mewing. Minutes later the bird appeared at the foot of a spruce tree about, 15 feet away from us. We could clearly see the blackish cap and rusty undertail coverts on this slate grey bird. It remained in the open for several minutes before moving out of sight. However, during that day we heard it calling frequently and saw it again on four or five occasions in the same area. As both of us are from southern Ontaric where Catbirds are a common breeding species, there could be no doubt in our minds as to the bird's identity.

According to Jehl and Smith (Birds of the Churchill region, Manitoba. Manitoba Museum of Man \& Nature, Spec. Publ. No. 1, Winnipeg, 1970) the Catbird has not previously been recorded at Churchill. However, two residents of Churchill, Angus and Berenice McIver, mentioned seeing a Catbird near Churchill about 15 years ago. That bird was at Herriot Creek, which flows into the Churchill River about 20 miles south of the town of Churchill.

Godfrey (The birds of Canada. Natl. Mus. Can. Bull. 203, 1966) notes the accidental occurrence of the Catbird north to Lesser Slave Lake. 